\title{
PATCHY WORLD. PRIVATISATION AS THE DRIVING FORCE BEHIND THE EVOLUTION OF LABOUR RELATIONS IN POLAND ${ }^{1}$
}

\begin{abstract}
Over the past three decades, Poland's economy has experienced a deep structural change in terms of ownership: from almost entirely state-owned to predominantly private, and from relatively consolidated to largely fragmented. The shift in the dominant form of ownership has been arguably the key factor behind the profound reconfiguration of work and employment relations, which has become fragmented and, to a large degree, subject to the voluntarist behaviour of employers. The article follows the changes in the social perceptions of the labour market in the context of ownership structure and the evolution of the economic mentality of Poles, using empirical data collected in the course of longitudinal research conducted at the Warsaw School of Economics (SGH).
\end{abstract}

Keywords: privatisation, labour relations, employees, employers, trade unions, survey research

* Dr, Institute of Philosophy, Sociology and Economic Sociology; e- mail: jczarz@sgh.waw.pl

1 This article is published as part of the research project entitled 'PREWORK: Young precarious workers in Poland and Germany: a comparative sociological study on working and living conditions, social consciousness and civic engagement' supported by the National Science Centre in Poland (NCN) and Deutsche Forschungsgemeinschaft, grant no. UMO-2014/15/G/HS4/04476, DFG: TR1378/1-1. 


\section{INTRODUCTION}

Over the past quarter of a century, privatisation has left a deep mark on the face of work and employment relations in Poland. While in 1990 52\% of all people in employment worked for the public sector, by 2015 the share has fallen to $22 \%$. The ownership structure corresponds to the classification of enterprises due to the volume of employment: over $96 \%$ (with some $40 \%$ of the workforce on the payroll) of all economic entities are micro firms (fewer than 10 workers), virtually all of them private. The most significant consequences for work and employment relations brought about by privatisation are arguably their advanced fragmentation (and individualisation), advanced pluralisation in the private sector in contrast to feeble (yet present) corporatist arrangements in the public sector, strong voluntarism of private employers and the opportunistic attitudes of foreign capital (multinational companies included) taking advantage of the clumsy local institutional environment [e.g. Gardawski 2009]. Autonomous regulation of labour relations nearly collapsed with the atrophy of collective bargaining, which is only slightly compensated for by tripartite social dialogue.

The article presents and analyses the impact of privatisation on labour using data collected in the course of research conducted at the Warsaw School of Economics (SGH) since the early 1990s. The perspective adopted in the article is centred around the social perceptions of work and employment relations and their institutions in a dynamic way, i.e., changes over time are discussed. In particular, the issues in focus are workplace preferences (in terms of sector of ownership), outlook on the collective dimension of work and employment relations, and capacity for the aggregation of individual interests by either side of labour relations (joining organisations representing the interests of employees or refusing to do so).

Institutional changes (the shift in the ownership structure) have undoubtedly affected the social perception of work and employment, as well as the economic mentality of workers. On the other hand, transformations within the former have also had an impact on the latter (changing attitudes towards working for the private and public sector, the level of entrepreneurial inclinations, the propensity to sell shares/stock by employees of state-owned enterprises subjected to privatisation). In other words, it is the classic agency-structure problem [Giddens 1979; Archer 2000] which is hereinafter examined.

The article is organised as follows: in the opening section, a synthetic account of contemporary Polish capitalism in the Central and Eastern European context is offered, with a special focus on labour relations, which constitute an important analytical dimension in the majority of the most cited comparative models of ca- 
pitalism. This is followed by a section summarising the effects of the privatisation process. In the subsequent section, the impact of privatisation on the economic mentality and labour relations is examined using the empirical data from the research which has been conducted at the Warsaw School of Economics (SGH) since the early 1990s. The next section concentrates on the changing position of the public sector in the labour relations context. The concluding section brings together possible future scenarios and potential directions of research in the field of labour relations in the predominantly private economy.

\section{SKETCHING THE CONTEXT: POLAND'S CAPITALISM}

As privatisation is the leitmotif of the article, some background structural information of Poland's economy needs to be provided. Undoubtedly, what we are dealing with is a "market economy", yet there are lively debates on the degree of market coordination in the domestic economy. Contemporary comparative studies in political economy stress the diversity of modern capitalism [e.g. Albert 1993; Hall and Soskice 2001; Amable 2003, Becker 2009]. The main protagonists of the debate on capitalisms are arguably Hall and Soskice [2001], whose dichotomous analytical framework splitting market economies into "coordinated" and "liberal" (the archetypal coordinated market economy - or CME - being Germany, and the liberal market economy - or LME - being the USA/UK) has long been the major point of reference. However, few models only have a solid empirical basis in quantitative data, with the notable exceptions of Amable [2003] and most recently Próchniak et al. [2016].

Poland, as well as other parts of the Central and Eastern European (CEE) region with a post-socialist background, has been incorporated into analyses relatively recently. A number of authors have claimed that in a post-socialist world devoid of capital resources of its own, "capitalism without capitalists" [Eyal, Szelenyi and Townsley 1998] would arrive "from without" [King, Szelenyi 2005] with foreign direct investment (FDI) becoming the main engine for economic development, leading to the emergence of a "dependent market economy" (DME). The DME is supposedly present in the Visegrád (or V4) countries (the Czech Republic, Hungary, Poland and Slovakia) marked by "dependence" on foreign capital [Nölke and Vliegenthart, 2009: 680]. That claim is reinforced by Myant and Drahokoupil [2010] branding the V4 (extended to cover Slovenia) an "FDI-based (second-rank) market economy". Jasiecki [2013] does not contest the "dependency" claim but asserts that Poland varies from the rest of the cluster as it is less reliant on FDI or exports than the other three countries, with its substantial 
industrial output and internal market. Bugaj [2015] also embrace the DME thesis, calling Poland an "assembly platform" for more advanced economies. Bohle and Greskovits [2012] label Poland (and the whole V4) a case of "embedded neoliberalism", where the struggle between marketisation and social protection takes place with neither prevailing, unlike in "neoliberal" (market-oriented Baltic states) or "neo-corporatist" (welfarist Slovenia) countries [Bohle and Greskovits 2012: 138-181]. The eminent position of FDI in the CEE is seen as a key factor differentiating the cluster from the rest of the former Eastern Bloc: the "liberal dependent capitalism" identified in the states which were admitted to the EU in 2004 is contrasted with the "patrimonial capitalism" of the former USSR states or South-Eastern Europe [King 2007].

Labour relations (equivalent to industrial relations ${ }^{2}$ ) constitute a separate analytical dimension in most of the widely cited models of capitalism. They are usually built in a derivative way, by reference to industrial relations literature. Regarding Poland, there is a striking symmetry between political economy studies and industrial relations studies: in both cases, attempts to classify Poland are hardly conclusive. The starting point would be a specific blend of the remnants of the "monocratic" system of industrial relations (typical of authoritarian state socialism) which broke down in 1980-81, replaced briefly by the "conflict-driven" model after emergence of "Solidarność", which in turn was succeeded by a peculiar unitary model, resting on semi-independent trade unions (OPZZ) and lasting until 1989 [e.g. Morawski 2017]. Over twenty years ago, Morawski [1995] suggested that "as usual in Poland, some hybrid will emerge". There are relatively new accounts that only reinforce that thesis [e.g. Bechter et. al., 2012], stressing the gap that remains between the public and private sector. Poland, just like the entire CEE, is portrayed as a "mixed" or "empty" case, "due to the fact that collective bargaining coverage, the organisational density of social partners and their fragmentation is low or sometimes even non-existent, collective bargaining is also rather decentralised" [Industrial Relations in Europe 2012, 2013: 47]. However, in the public sector, industrial relations are described as "state-centred". Furthermore, other diagnoses of the parallel co-existence of multiple institutional orders of labour relations have been repeatedly formulated over the years [e.g. Morawski, 1995; Gardawski, 1999; Kozek, 2003], which suggests the segmentation is durable. Still, there is no consensus about what

2 Despite terminological pluralism present in contemporary academic studies of work and employment, the two notions closely correspond, according to the International Labour Organisation (ILO). The reason for using the term "labour relations" is a clear demarcation of the field the notion allows. 
particular lines of division exist and where they come from. Morawski [1995] claimed there was a dichotomy of public and private sector but later concepts appear more nuanced [e.g. Meardi 2003, Gardawski 2013, Czarzasty 2014a] and tend to stress discrepancies between the domestic and foreign segments of the private sector. Most likely the divergence in views could be explained by the fact they were formulated in different circumstances (before and after the acceleration of the FDI influx and its accumulation at a level where its impact on labour relations became visible).

\section{THE PRIVATISATION OF THE POLISH ECONOMY}

Regardless of varying portrayals of the Polish economy, the common denominator seen in the most eminent analyses listed above is the shared acknowledgement of its capitalist character. As a capitalist economy is founded on private ownership, it seems essential to provide an account of the process that led to the transformation of the national economy from being largely stated owned (prior to 1989) to largely private owned (post-1989), i.e., privatisation. Compared to the other European socialist states, Poland displayed many oddities, like largely non-collectivised agriculture and a relatively large private sector composed of small-businesses (where a specific social milieu of protocapitalists, called prywaciarze, existed). Despite alterations in methodology for data aggregation and the presentation made by the Central Statistical Office (GUS) in the 1990s, the dynamics of change with regard to the ownership structure of the national economy can be captured in quite an accurate way (Table 1). It is evident that the momentum occurred in the first decade of the transformation; in the $21^{\text {st }}$ century, the impetus was gradually lost.

TABLE 1. Shares of the public and private sector in Poland (1990-2015)

\begin{tabular}{|c|c|c|c|c|}
\hline \multirow{2}{*}{} & \multicolumn{2}{|c|}{ GDP (\%) } & \multicolumn{2}{c|}{ Employment (\%) } \\
\cline { 2 - 5 } & Public sector & Private sector & Public sector & Private sector \\
\hline 1990 & $69^{(\mathrm{b})}$ & $31^{(\mathrm{b})}$ & 52 & 48 \\
\hline 1995 & 34 & 53 & 39 & 61 \\
\hline 2000 & 26 & 63 & 28 & 72 \\
\hline 2005 & 22 & 67 & 28 & 72 \\
\hline 2010 & 20 & 68 & 25 & 75 \\
\hline 2015 & 17 & 71 & 22 & 78 \\
\hline
\end{tabular}

(a) gross value added only, no taxes; ${ }^{\text {(b) }}$ data reported with no taxes deducted

Source: Central Statistical Office (GUS), Statistical Yearbooks of Poland (1991-2016) 
There were several reasons for the structural nature underneath the shift in proportions between the two sectors. First, the grass-roots (founding) privatisation, i.e., starting up businesses on a massive scale, which contributed to the swiftly growing position of the private sector between 1990 and 1995. Behind the crude numbers, there is a fascinating story of entrepreneurial spirit erupting in that period, whose drivers are very complex. On the one hand, aspiring entrepreneurs would take advantage of the window of opportunity opening, and pursue the dream of "being your own boss" (the issue will be further developed). On the other hand, going into self-employment was often a necessity, the only available option to escape unemployment for people being made redundant during the initial phase of industrial restructuring [Gardawski 2001a]. Second, FDI quickly grew from the mid-1990s onwards, done mainly by multinational corporations (MNCs), both in brownfield and greenfield investments [Kosztowniak 2018]. Thirdly, the de-nationalisation of state property was initiated in the early 1990s, the terms of which denote not only privatisation per se (partly overlapping with FDI, as brownfield investments meant simply the sale of state-owned assets to foreign-owned enterprises) but also so-called commercialisation (the transformation of state-owned enterprises into corporations under sole or partial control of the state) [Kozarzewski 2006].

Regarding grass-roots (founding) privatisation, the following aspects of the process need to be highlighted: 1) its quantitative effects (the number of business operations representing that type of ownership, their share in employment and GDP), 2) social attitudes towards entrepreneurship and self-employment, 3 ) the consequences for labour relations (the fragmentation and precarisation of labour). Regarding FDI, the same aspects (numerical terms, social attitudes and the impact on labour relations) should be discussed. Finally, de-nationalisation (being a very complex field) will be intentionally narrowed to the dimension of employee privatisation, towards which very high hopes had once been addressed, later turning largely into disappointment with the almost complete marginalisation of employee ownership. It was possible for employee privatisation to follow two main paths: direct or indirect. In the case of the former, the state-owned enterprise (or its assets) could be handed over or contribute to the newly created employee company (spótka pracownicza). In the case of the latter, the employees could acquire - for free - up to $15 \%$ of the stock/shares controlled by the state in the newly created company/corporation, or acquire stock/shares in the capital of the State Treasury company on their own or via the employee company.

As the Central Statistical Office reported, as of 2015 there was a total of 2 million active economic entities in Poland (1.6 million, according to Eurostat, 
as of 2015). Furthermore, the share of self-employment in the entire employment structure is also high, as nearly one in five workers is self-employed $(13 \%$ do not do not employ any staff, $4 \%$ are employers). SMEs provide half $(51.1 \%$ as of 2015) of Poland's gross value added (GVA), and micro firms' contribution amounts to $15.8 \%$. Individuals engaged in a business activity (as opposed to legal persons) constitute $89 \%$ of all micro firms. Average employment in SMEs in merely 5.4 people per company (the EU mean is 6 ). The survival rate of newly founded SMEs is fairly high: $67 \%$ continue to operate for more than a year, $54 \%$ still exist after two years but only $41 \%$ function after five years [Sektor MSP w Polsce i UE 2017].

For any semi-peripheral economy, FDI is a crucial source of capital. As mentioned earlier in the article, compared to the other CEE countries, Poland is often seen as less dependent on that particular leverage of economic development, mostly due to the size of the internal market [see: Jasiecki 2013]. Nevertheless, FDI has been an important factor of not only economic but also institutional transformation. As of 2016, 26,015 foreign-owned enterprises (defined in line with the methodological standards, i.e., only those with at least $50 \%$ of stock/shares owned by foreign entities are counted) operating in Poland employed 1.88 million staff. Contrary to popular belief, foreign capital in Poland is not represented by large, multinational corporations only. Actually, two-thirds of foreign-owned enterprises in Poland are micro firms, while large enterprises (250+ employees) constitute only $5.5 \%$ of foreign-owned enterprises [GUS 2018a].

Since the privatisation of state property first began in 1990, by 2012, a total of 1563 employee companies had been registered. It is not known how many have survived until the present while retaining the status. According to the latest data released by the government, by the end of 2015, a total of 2308 state-owned enterprises (SOEs) had undergone direct privatisation, of which 1,402 were leased, 253 contributed to employee companies, 586 were sold, and in the case of the remaining 67 , a mixed form of direct privatisation was used. In other words, in over $70 \%$ of cases of privatisation, employee companies were involved [MSP 2016]. However, employee companies slowly vanished. According to Jarosz [2002], in employee companies that were established with a view to leasing assets of the former state-owned enterprise, staff would sell their shares/stock to managers on average three years after the registration of the company. 


\section{STUDYING THE IMPACT OF PRIVATISATION ON ECONOMIC MENTALITY: METHODS AND DATA}

Taking into account the scope and intensity of structural and institutional changes discussed in earlier sections, there is no doubt that the process of re-introducing capitalism in Poland has left a mark on the economic mentality of society [Hardy 2009; Gardawski 2009]. Yet, there are not many studies which make use of longitudinal data to explore the changes in economic mentality over time in the course of privatisation processes. The notion of economic mentality used hereinafter is adopted from the school of research developed at the Warsaw School of Economics (SGH) - previously known as the Central School of Statistics and Planning (SGPiS) - since 1986. Economic mentality comprises normative visions of the economy which aggregate into a desirable model of the economy ("the way it should be"), branded the "well-ordered economy" [Gardawski 2017].

Using data on the economic mentality of Poles produced by the survey research conducted at $\mathrm{SGH}$, in the following section, the interlink between economic mentality and labour relations in the context of the economy undergoing privatisation is analysed. In particular, the data employed come from the following studies: Workers 1991 (Robotnicy 1991), two waves of Working Poles (Polacy pracujący) performed in 2005 and 2007, Polish Entrepreneurs (Polacy przedsiębiorcy) of 2011 and PREWORK PAPI (Młodzi na rynku pracy województwa mazowieckiego) finalised in mid-2018. In 1991, the sample comprised industrial workers ( $\mathrm{n}=2,817)$. In 2005 and 2007, there were nationwide samples of adults used ( $\mathrm{n}=900$ in 2005 and $\mathrm{n}=1,021$ in 2007). In 2018, a quota sample was used, constructed with a view to mirroring the key socio-demographic characteristics of the young cohort (aged 18-30) in the general population of Poland $(n=1,000)$. Besides covering the core variables which form the so-called "well-ordered economy index", the questionnaire employed in each survey contains a wide spectrum of questions related to various aspects of social life, ranging from perceived class status to living conditions.

3 In the article, PREWORK PAPI was chosen as the shortened name for the study, as it was done as a part of the PREWORK project but it was not the only survey study. Following the 2016 parallel survey studies in Poland and Germany, conducted with the use of CATI (computer-aided telephone interview), in 2018, another, more extensive survey was completed in Poland only with the use of PAPI (pen-and-paper interview). The results are analysed in the article. 


\section{PRIVATISATION, ECONOMIC MENTALITY AND LABOUR RELATIONS: ANALYSIS OF THE INTERLINKS}

Exploring the interlinks between privatisation, economic mentality and changing labour relations, the focus in the subsequent analysis is on the variables (survey questions) of the workplace and the form of employment preferences, treated as correlates of economic mentality. Opinions on the preferred workplace registered between 1991 and 2018 are presented in Table 2. It must be stated up front that in the most recent survey, run in 2018, no question about ownership sector appears. Instead, the respondents were asked to express their preferences with regard to the form of employment. In basic terms, it means choosing between dependent employment and self-employment.

TABLE 2. Preferred workplace (1991-2018)

\begin{tabular}{|c|c|c|c|c|}
\hline $\begin{array}{l}\text { Preferred workplace / } \\
\text { form of work }\end{array}$ & $\begin{array}{c}\text { Workers } \\
1991 \\
(\mathrm{n}=2,817)\end{array}$ & $\begin{array}{c}\text { Working } \\
\text { Poles } 2005 \\
(\mathrm{n}=900)\end{array}$ & $\begin{array}{c}\text { Working } \\
\text { Poles } 2007 \\
(\mathrm{n}=1,021)\end{array}$ & $\begin{array}{c}\text { PREWORK } \\
\text { PAPI } 2018 \\
(\mathrm{n}=1,000)\end{array}$ \\
\hline $\begin{array}{l}\text { Public sector (employee companies } \\
\text { and cooperatives included) }\end{array}$ & 55.4 & 49.9 & 39.7 & \multirow{4}{*}{60.1} \\
\hline Private sector, of which: & 25.3 & 15.8 & 24.5 & \\
\hline Domestic ownership & 4.5 & 9.1 & 13.4 & \\
\hline Foreign ownership & 20.8 & 6.7 & 11.1 & \\
\hline Self-employment (solo and employer) & 15.5 & 24.9 & 29.1 & 37.3 \\
\hline Hard to say & 3.8 & 9.2 & 6.7 & 2.6 \\
\hline
\end{tabular}

Source: developed from Czarzasty (2010), figures for 2018 - own calculations based on original data from "Młodzi na rynku pracy województwa mazowieckiego" (PREWORK/PAPI)

Table 2 shows that the shares of those who would prefer to work for the domestic private sector increased at the expense of the public sector and foreign-owned private enterprises. Throughout the 1990s and early 2000s, there was seemingly a disenchantment with foreign-owned enterprises, as the mythologised picture of Western welfare capitalism (of which foreign companies were seen as agents) was confronted with the realities of actual employment with foreign-owned companies [e.g. Gardawski 1996; Dunn 2008; Mrozowicki 2011]. Still, in 2007, the public sector remained the most favoured option, despite having lost some of its appeal. Self-employment would systematically gain popularity, and the share of those wanting to pursue that path had doubled by 2007 , and continues to climb in the current decade. What needs to be stressed is that ostensible self-employment 
seems not to be widespread: in 2018, only one in seven self-employed workers would admit to being forcibly pushed into such a status.

Tackling the problem from another angle and aggregating the "non-self-employment" responses produces the following results: in 1991, $81 \%$ of respondents opted for a job, in 2005 - the figure was $66 \%$, in $2007-63 \%$, and in $2018-60 \%$. So, while there is a steady decrease in the number of those favouring dependent employment, over the past 11 years it has been moderate.

Moving beyond workplace preferences, a crucial question to be raised in discussing the effects of the shift towards private property on labour relations would be how capitalism is assessed. Again, challenging the popular belief that capitalism is accepted unconditionally and unanimously brings interesting results: in 2018 , only $46 \%$ of respondents tend to think that "a capitalist economy based on private entrepreneurship is the best economic system for our country", while one third of respondents had no definitive opinion, and one fifth disagreed. Only $12 \%$ would like to see all state and public-owned enterprises privatised. Juxtaposing those opinions with selected normative visions of the economy reveals an ambivalence in attitudes: on the one hand, competition is widely applauded as the basic regulatory mechanism of the economy (77\%), on the other hand, the idea that employers could have a right to fire employees that are not needed at the moment, with no financial compensation, is strongly rejected (64\%). Those who accept the very existence of unemployment are outnumbered, albeit slightly, by those who think otherwise ( $37 \%$ and $39 \%$, respectively).

On the other side of the coin, there is the outlook on the economy of business owners/co-owners representing the SME sector. The results come from the 2011 survey and form a significant frame of reference for the discussion of the impact of privatisation on labour relations for at least two reasons: 1) importance of the SME sector for the national economy and labour market (as of 2016, SMEs make up $99.8 \%$ of all enterprises, and $96 \%$ are micro firms only, contributing $50 \%$ of Polish GDP and being workplaces for $69 \%$ of all people in employment) [GUS 2018b]; 2) the nature of labour relations in that particular type of enterprise, in the large part, is determined by the fact that $80 \%$ of Polish SMEs are family-owned [Badanie firm rodzinnych 2009], which translates into strong inclinations of owner-managers to paternalistic and autocratic behaviour [Gardawski 2001b; Czarzasty 2014b]. In 2011, three out of four respondents shared the view that "owners or managers usually make better representatives of employee interests than trade union leaders, because they know what their people need better and can take care of them better". Still, at least in the case of micro firms (and to a large extent small ones), the dilemma is purely hypothetical, because labour 
relations in workplaces of that size are correctly described as "a vacuum" [Rainnie 1989], with no formal worker representation, which results in interest bargaining conducted informally [Transfer 2007]. Notwithstanding, SME owner-managers in the vast part (83\%) tended to believe that the interests of their employees are adequately secured vis-à-vis employers by general legal regulations. However, only $46 \%$ agreed that in relations with employees, their own interests as employers are protected well enough. More than half $(56 \%)$ of the sample would speak favourably on employees' right to "information and consultation".

TABLE 3. Institutions of labour relations (1991-2018)

\begin{tabular}{|c|c|c|c|c|c|c|c|c|c|}
\hline & 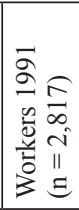 & 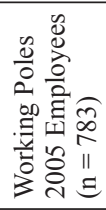 & 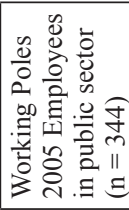 & 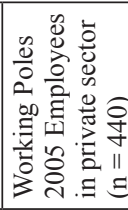 & 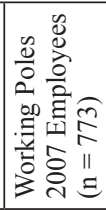 & 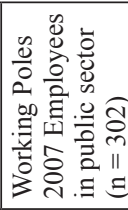 & 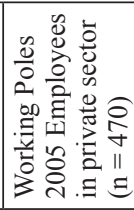 & 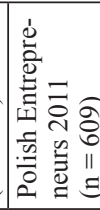 & 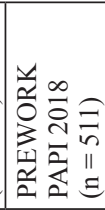 \\
\hline $\begin{array}{l}\text { Presence of } \\
\text { trade unions } \\
\text { in the work- } \\
\text { place }\end{array}$ & 100.0 & 35.5 & 64.2 & 12.9 & 32.6 & 61.1 & 14.2 & 3.1 & $25.0^{*}$ \\
\hline \begin{tabular}{|l|} 
Union \\
density \\
\end{tabular} & 47.7 & 14.3 & 27.0 & 5.7 & 13.7 & 26.9 & 5.3 & - & 1.0 \\
\hline $\begin{array}{l}\text { Presence } \\
\text { of works } \\
\text { councils } \\
\text { in the work- } \\
\text { place } \\
\end{array}$ & - & - & - & - & 15.8 & 25.3 & 9.7 & 9.7 & $25.0^{*}$ \\
\hline $\begin{array}{l}\text { Presence of } \\
\text { collective } \\
\text { agreements } \\
\text { in the work- } \\
\text { place }\end{array}$ & - & 62.9 & 62.4 & 64.4 & 51.7 & 51.8 & 51.5 & - & 37.3 \\
\hline
\end{tabular}

Source: adapted from Czarzasty (2010), figures for 2011 and 2018 - own calculations based on original data from "Badanie właścicieli małych i średnich przedsiębiorstw" (Polish Entrepreneurs) (2010-2011) and "Młodzi na rynku pracy województwa mazowieckiego" (PREWORK/PAPI)

* In the 2018 survey, there was a question whether there was any form of organised worker representation in the workplace, which is why the same figure is given twice (for trade unions and works councils)

As remarked in the opening part of the article, labour relations in Poland have remained weak in terms of institutionalisation. It is not difficult to notice that over the years, union density and the extent of collective bargaining has been falling steadily. The last survey where there were separate questions regarding the presence of trade unions and works councils was carried out in 2011. The latest 
data (2018) show only a general presence of organised worker representation of any type. Keeping in mind that works councils have mostly disappeared in the 2010s, affirmative responses to the question of whether there is any organised worker representation in the workplace with all probability indicate the existence of trade unions.

Declared trade union density fell, as did union presence at the workplace level. In the context of the article, the most promising field of analysis would be union density in the public sector, as long as we are interested in capturing long-term dynamics. In the 1991 survey, all enterprises (383 in total) were state-owned; thus, the figure could be assumed to correspond to that recorded for public sector employees in 2005 and 2007. Thus, unionisation level fell by almost a half (from $47.4 \%$ in 1991 to $26.9 \%$ in 2007). Union presence shrank too, albeit not so dramatically. The dynamics in the presence of collective agreements could be analysed between 2005 and 2018, and comparing the "general" (for all employees) figure, there is a steady decrease.

It is advisable to refer to data on the incidence of workers' interest representation in those companies which, due to the number of employees, are bound by legal regulations on trade unions (at least 10 employees) or works councils (at least 50 employees). In 2007, in enterprises with 11-20 staff, the unionisation level was merely $1 \%$, in those with $21-49$ employees $-2.6 \%$, in those with 50-99 employees $-12.5 \%$, and in companies with 100-249 employees $-19.4 \%$. Works councils existed in $32 \%$ of medium-sized (at least 50 staff) companies.

Seeking the answer to the question why the institutionalisation of labour relations is weak, it seems worthwhile to look at attitudes towards any collective forms of interest aggregation and articulation by any side of industrial labour relations. Considering the generally low level of both union and employer organisations' density, it translates into the question of why most respondents do not belong to any organisation. Regarding employers, in 2011, only one-fifth of the sample confirmed that they were a member of an employer's or business association. Those admitting to not being associated anywhere usually explained their lack of involvement by saying that "they do not want to" $(55 \%)$, with a much smaller number stating that "there is no organisation they would like to join" (17\%). Only 5\% admitted that their company may need any aid from an employer's organisation, but there is definitive (61\%) support for the idea that "employer organisations should have more influence on the government's economic policy than they do now". Regarding the employees who were questioned in 2018, the main reasons given for abstaining from a union were as follows (only responses 
given by those in employment are counted): $62 \%$ replied that "they do not want to", while $22 \%$ claimed "there is no organisation they would like to join". On the other hand, an overwhelming part (57\%) agrees with the statement that "in all enterprises, except for small, family-owned businesses, there should be trade unions present". Moreover, the majority (59\%) support the idea of trade union involvement in economic affairs and union empowerment (through co-determination) at the enterprise level (55\%). In other words, there is non-committal sympathy for organisations voicing collective interests expressed by both sides of the labour relations scene.

While business-owners of the SME sector speak about labour conflict, there is a clear pattern visible: the share of those believing in the conflict-driven nature of labour relations steadily falls as the perspective lower from macro- to microlevel. While $57 \%$ would agree with the general statement that "in our country there are conflicts, antagonisms, and divisions between management and trade unions in enterprises", $30 \%$ were ready to acknowledge the existence of conflicts between management and employees, and the share was even smaller $(28 \%)$ of those admitting there were conflicts between management and employees in private enterprises. So the smaller the picture, the less decisive the respondents were regarding the presence of labour conflict. As for employees, in the 2018 PREWORK survey, nearly half (49\%) of respondents said there are conflicts between owner and managers of large companies and their employees. It is a considerably higher figure $(+20 \%)$ than in the case of employers asked the same question in 2010 , yet the gap could plausibly be explained by the paternalistic orientation displayed by the majority (73\%) of SME business-owners, who would subscribe to the claim that "owners or managers of companies usually better represent the interests of employees than trade union leaders. They (owners/managers) know better what the people need and can take better care of them".

\section{SHIFTING PREFERENCES: IS THE PUBLIC SECTOR NO LONGER THE PLACE TO BE?}

In the previous sections of the article, the changing attitudes of employees towards various sectors of the economy distinguished in ownership terms are examined. In this section, the public sector is the subject of closer scrutiny, as it is arguably the field where one can find the most convincing evidence for privatisation succeeding - perhaps irreversibly - in terms of reshaping the economic mentality of Poles, with its resulting consequences for labour relations. 
The advanced fragmentation of the enterprise sector, the workplace-based model of unionism and the lack of political will to improve the flawed regulatory framework (a notable example of which is the long-lasting battle to revise the Trade Unions Act, narrowing the right of association) effectively cut off a significant part of the workforce from access to union representation. Facing the fragmented world of labour stands the equally disjointed world of business.

It seems that on both sides of the labour relations scene, there is a tendency towards the model of interest representation without membership, so this brings the "representative claim" [Saward 2010] into the discussion. On the other hand, huge gaps between actual and potential (preferences) involvement with organisations and the general acceptance of institutions of labour relations bring to mind the ambivalent stance towards the market economy. Gardawski [1996: 135] would call it "privatisation dissonance": in general, privatisation was accepted, but in particular, rejected. In other words, as long as it did not directly affect the respondents and their workplace, it would be met with approval. The same-seemingly schizophrenic - thinking applied to unemployment.

Over the years, the resistance of public sector workers to the ruthless power of the market was blunted. It was done, first of all, by the shifting proportions among sectors of the economy, leading to the "voice" of the working class - once loud in the large state-owned enterprises and feared by the political class - being replaced by a mutiny of segmented workers. Secondly, as demonstrated in Table 2, perceptions of various sectors of the economy have changed, with the public sector losing its appeal as a "safe haven", and the private sector, especially its domestic branch, gaining attractiveness as a workplace. What should not be overlooked is the negative impact of "cheap state" logic and "austerity, Polish-style" on working conditions in the public sector, in particular, the "national budgetary sphere". Regarding the former, the increasing popularity of the New Public Management doctrine (which strangely coincided with its setback in Western Europe), noticeable since the early 2000s in Poland, translated into a systematic reduction of employee entitlements (pay and non-pay, including special retirement schemes) in many branches of the public sector, such as the police (early retirement schemes) or education (entitlements secured by the Teachers' Charter, whose very existence has come under constant assault). Not to be ignored is the populistic tone of public debate on trimming those entitlements (not accidentally referred to as "privileges"). Never being very attractive in terms of wages, those occupations have lost many of the non-pay advantages they used to offer. Thus, the trade-off (better pay or social entitlements) that labour market entrants once faced while weighing up employment options is largely gone, becoming the 
main threat for generational turnover and workforce reproduction in specific parts of the public sector [Kozek at al. 2011]. This is manifested inter alia by the huge number of vacancies in the police force or by the alarmingly advanced average age of medical doctors and nurses. Regarding the austerity measures, suspending the indexation of wages in the public sector in 2010 (still in force), a key component of the policy aiming at the stabilisation of public finances, has led to a deterioration of real wages of the employees affected. Considering the upswing in the general economic cycle, whose effects have been visible since 2013, and the growing shortage of skilled labour, the public sector may soon turn into the least attractive destination for job seekers, apart from microfirms. While the private sector has not improved much (apart from rising wages) in the aspect of labour relations, the public sector has experienced a deep fall therein.

\section{STATE OF PLAY, POSSIBLE FUTURE SCENARIOS AND POTENTIAL DIRECTIONS OF RESEARCH}

In the late 2010 s the economy is predominantly private. The public sector has lost its appeal, mostly because of the erosion of social (non-wage) entitlements and special retirement regulations (including state-financed pensions plans) being dismantled. Adding the overall good performance of the national economy, and the radical shift in the labour market struggling with a shortage of skilled labour and the deterioration of real wages in the "national budgetary sphere" due to the austerity policies of the 2010s, the competitive position of the public sector as employer versus the private sector has been weakened. Furthermore, self-employment has been gaining popularity as an individual labour market strategy.

It would definitely be interesting and potentially fruitful to closely examine the link between strong preferences for self-employment and the alleged "normalisation of precarity" [Karolak, Mrozowicki 2017], the perception of which seems to have changed in the direction of being accepted as an inevitable phenomenon of the labour market. The field of precarious work has only recently become the subject of empirical studies in Poland. It is probably a consequence of the lack of empirical evidence: the debate of the precariat has been mostly theoretical, with notable exceptions posed by the works of Desperak and Śmiałek [2010], Kozek, Ostrowski and Kubisa [2005], and more recently by the ongoing POLPAN research programme and the binational PREWORK project. In researching precarious work methodological challenges also play part: precarious workforce is extremely dispersed and individualistically oriented, as field research in the PREWORK project reveals. The very little that is known about the involvement 
of precarious Polish workers in the collective dimension of labour relations shows that it is marginal. Nevertheless, in 2018 the majority (two-thirds of the sample in the discussed survey) of young people would still opt to become a contracted employee rather than pursue self-employment. Taking into account the ongoing individualisation of labour relations, the structure of the enterprise sector with an overwhelming share of microenterprises, and the weakness of industrial relations institutions, it seems that the fragmentation of the workforce and its inability to define, articulate and voice their collective interests will not only be calcified but is even likely to deepen.

\section{CONCLUSIONS}

Poland's economy contrasted with the rest of the Eastern Bloc countries on the eve of the 1990s, with a relatively well-developed private sector of economy, which, nevertheless, still looked small compared to the public sector. Following the take-off of the privatisation process, the relations between the ownership sectors changed quickly and deeply. However, the shrinking (in terms of employment) public sector managed to retain appeal as a potential workplace for a long period, according to the results of research on economic mentality conducted at SGH. In recent years, however, the attractiveness of the public sector as a workplace has largely evaporated. The analysis carried out in the article suggests that nowadays it is not a matter of the sector (public versus private) but rather the contractual form of work that seems to be the major criterion in formulating and implementing individual labour market strategies in terms of one's preferred placing. As the ownership factor no longer appears to be of fundamental importance, it may be seen as conclusive evidence that the privatisation process has left an indelible mark on labour relations in Poland and the economic mentality of working Poles.

\section{REFERENCES}

Albert Michel. 1993. Capitalism against capitalism. New York: John Wiley and Sons Incorporated.

Amable Bruno. 2003. The diversity of modern capitalism. Oxford: Oxford University Press.

Archer Margaret. 2000. Being human: The problem of agency. Cambridge: Cambridge University Press.

Badanie firm rodzinnych. 2009. Warszawa: Polska Agencja Rozwoju Przedsiębiorczości (PARP).

Becker Uwe. 2009. Open varieties of capitalism: continuity, change and performances. Hundmills: Palgrave. 
Bechter Barbara, Bernd Brandl, Guglielmo Meardi. 2012. "Sectors or countries? Typologies and levels of analysis in comparative industrial relations". European Journal of Industrial Relations 18.3: 185-202.

Bohle Dorothee, Bela Greskovits. 2012. Capitalist diversity on Europe's periphery. Ithaca, London: Cornell University Press.

Bugaj Ryszard. 2015. Plusy dodatnie i ujemne, czyli polski kapitalizm bez solidarności. Warszawa: Poltext.

Czarzasty Jan. 2010. Stosunki pracy $w$ handlu wielkopowierzchniowym w Polsce. Warszawa: Of. Wyd. SGH.

Czarzasty Jan. 2014a. Stosunki pracy i kultura organizacyjna przedsiębiorstw. In: Rokowania zbiorowe w cieniu globalizacji. Rola i miejsce zwiazków zawodowych w korporacjach ponadnarodowych, J. Czarzasty (ed.), 150-181. Warszawa: Scholar.

Czarzasty Jan. 2014b. "Stosunki pracy w małych i średnich przedsiębiorstwach”. Problemy Polityki Społecznej 26(3): 135-153.

Desperak Izabela, Judyta Śmiałek. 2010. Młodzi w Łodzi - prekariat z wyższym wykształceniem. Raport z badań 2010. Łódź: Biblioteka Think Tanku Feministycznego.

Dunn Elizabeth. 2008. Prywatyzując Polskę, Warszawa: Wyd. Krytyki Politycznej.

Eyal Gil, Ivan Szelenyi, E.R. Townsley. 1998. Making capitalism without capitalists: Class formation and elite struggles in post-communist Central Europe. London-New York: Verso.

Gardawski Juliusz. 1996. Przyzwolenie ograniczone. Robotnicy wobec wolnego rynku i demokracji. Warszawa: Wyd. Nauk. PWN/Fundacja im. F. Eberta.

Gardawski Juliusz et al. 1999. Rozpad bastionu? Zwiąki zawodowe w gospodarce prywatyzowanej, Warszawa: ISP/Fundacja im. F. Eberta.

Gardawski Juliusz. 2001. Powracajaca klasa. Sektor prywatny w III Rzeczpospolitej. Warszawa: IFiS PAN.

Gardawski Juliusz. 2001. Zwiąki zawodowe na rozdrożu. Warszawa: ISP.

Gardawski Juliusz. (ed.). 2009. Polacy pracujacy a kryzys fordyzmu. Warszawa: Scholar.

Gardawski Juliusz. (ed.). 2013. Rzemieślnicy i biznesmeni. Właściciele małych $i$ średnich przedsiębiorstw. Warszawa: Scholar.

Gardawski Juliusz. 2017. "Klasy społeczno-ekonomiczne a normatywne wizje gospodarki", Kultura i Rozwój 1(2): 73-119.

Giddens Anthony. 1979. Central problems in social theory: Action, structure, and contradiction in social analysis. Berkeley: University of California Press.

Góra Marek. 1994. „Rynek pracy w Polsce”. Studia i Analizy 19. Warszawa: CASE.

GUS. 2018a. Działalność gospodarcza podmiotów z kapitałem zagranicznym w $2016 \mathrm{r}$. Warszawa: Główny Urząd Statystyczny.

GUS. 2018b. Działalność przedsiębiorstw niefinansowych w 2016 r. Warszawa: Główny Urząd Statystyczny.

Hall Peter, David Soskice (ed.). 2001. Varieties of capitalism: The institutional foundations of comparative advantage. Oxford: Oxford University Press.

Hardy Jane. 2009. Poland's new capitalism. London: Pluto Press.

Industrial Relations in Europe 2012, 2013. Brussels: European Commission.

Jarosz Maria. 2002. Prywatyzacja w Polsce 1990-2002. Warszawa: ISP PAN.

Jasiecki Krzysztof. 2013. Kapitalizm po polsku. Między modernizacją a peryferiami Unii Europejskiej. Warszawa: Scholar. 
Karolak Mateusz, Adam Mrozowicki. 2017. "Between normalisation and resistance. Life strategies of young precarious workers". Warsaw Forum of Economic Sociology 8:1(15): 7-32.

King Larry. 2007. Central European capitalism in comparative perspective. In: Beyond varieties of capitalism: Conflict, contradictions and complementarities in the European economy, B. Hanké, M. Rhodes, M. Thatcher (eds.), 307-327. Oxford: Oxford University Press.

King Larry, Ivan Szelényi. 2005. Post-communist economic systems. In: The handbook of economic sociology, N.J. Smelser, R. Swedberg, (eds.), 205-232. Princeton: Princeton University Press.

Kosztowniak Aneta. 2018. Zagraniczne inwestycje bezpośrednie a wzrost gospodarczy w Polsce $i$ wybranych krajach Europy Środkowej $i$ Wschodniej. Warszawa: CeDeWu.

Kozarzewski Piotr. 1996. Prywatyzacja w krajach postkomunistycznych. Warszawa: ISP PAN

Kozek Wiesława. 2003. Czy wyłania się model? In: Instytucjonalizacja stosunków pracy w Polsce, W. Kozek (ed.), 16-40. Warszawa: Scholar.

Kozek Wiesława (ed.). 2011. Gra u jutro ustug publicznych. Warszawa: UW.

Kozek Wiesława, Julia Kubisa, Piotr Ostrowski. 2005. "Bliżej Junk Job niż Working Poor. Nisko kwalifikowana nisko płatna praca w usługach w Polsce". Polityka Społeczna 10:1-8.

Meardi Guglielmo. 2002, "The Trojan horse for the Americanization of Europe. Polish industrial relations towards the EU”, European Journal of Industrial Relations 8(1): 77-99.

Morawski Witold. 1995. Korporatyzm: wyłanianie się nowych stosunków pracy w Polsce. In: Negocjacje. Droga do paktu społecznego, T. Kowalik (ed.), Warszawa: IPiSS.

Morawski Witold. 2017. "From industrial democracy to political democracy in Poland: On the rise and fall of Solidarity". Warsaw Forum of Economic Sociology 8:2(16): 7-24.

Mrozowicki Adam. 2011. Coping with social change: Life strategies of workers in Poland's new capitalism. Leuven: Universitaire Pers.

MSP. 2016. Kierunki prywatyzacji majątku Skarbu Państwa w 2016 r. Warszawa: Ministerstwo Skarbu Państwa.

Myant Martin, Jan Drahokoupil. 2010. Transition economies. Political economy in Russia, Eastern Europe, and Central Asia, New York: John Wiley and Sons.

Nölke Andreas, Arian Vliegenthart. 2009. "Enlarging the varieties of capitalism: The emergence of dependent market economies in East Central Europe". World Politics 61(4): 670-702.

Rainnie Al. 1989. Industrial relations in small firms: Small isn't beautiful, London: Routledge.

Próchniak Mariusz et al. (2016). "The emerging varieties of capitalism in CEE11 Countries - a tentative comparison with Western Europe". Warsaw Forum of Economic Sociology 7:2(14): 7-70.

Saward Michael. 2010. The representative claim. Oxford: Oxford University Press.

Sektor MSP w Polsce i UE. 2017. Warszawa: Polska Agencja Rozwoju Przedsiębiorczości (PARP).

Statistical Yearbooks of Poland. 1991-2016. Warszawa: Główny Urząd Statystyczny.

Transfer. European review of labour and research. 2007. Special Issue. February 13(1). 
Jan Czarzasty

\section{PSTROKATY ŚWIAT. PRYWATYZACJA JAKO SILA NAPĘDOWA EWOLUCJI STOSUNKÓW PRACY W POLSCE}

Streszczenie

Przez ostatnie niemal trzydzieści lat polska gospodarka przeszła długa drogę w procesie zmian własnościowych: od prawie całkowicie kontrolowanej przez państwo do w przeważającym stopniu prywatnej, od względnie skoncentrowanej (tj. zdominowanej przez dużych pracodawców) do dalece rozproszonej (z mikro- i małymi przedsiębiorstwami odgrywającymi główną rolę). Zmianę dominującej formy własności można wskazać jako kluczowy czynnik rekonfiguracji stosunków pracy i zatrudnienia, które stały się silnie sfragmentyzowane oraz podatne na woluntarystyczne zachowania pracodawców. Artykuł podsumowuje zmiany w społecznej percepcji rynku pracy w kontekście struktury własnościowej i ewolucji świadomości ekonomicznej Polaków, wykorzystując dane empiryczne zebrane w toku długoletnich badań sondażowych prowadzonych w Szkole Głównej Handlowej w Warszawie (SGH).

Słowa kluczowe: prywatyzacja, stosunki pracy, pracownicy, pracodawcy, związki zawodowe, badania sondażowe 